SURVIVAL OF THE FITTEST OR THE

FATTEST? EXIT AND FINANCING

IN THE TRUCKING INDUSTRY

\author{
Luigi Zingales
}

Working Paper 6273 
NBER WORKING PAPER SERIES

\title{
SURVIVAL OF THE FITTEST OR THE \\ FATTEST? EXIT AND FINANCING \\ IN THE TRUCKING INDUSTRY
}

\author{
Luigi Zingales
}

Working Paper 6273

http://www.nber.org/papers/w6273

\section{NATIONAL BUREAU OF ECONOMIC RESEARCH \\ 1050 Massachusetts Avenue \\ Cambridge, MA 02138 \\ November 1997}

I wish to thank Abhay Pande for interesting me in the trucking industry, Judy Chevalier, Kent Daniel, Colin Mayer, Antonio Merlo, Marzio Galeotti, Austan Goolsbee, Charlie Himmelberg, Vojislav Maksimovic, Steve Kaplan, Anil Kashyap, Sam Peltzman, Raghu Rajan, Fabio Schiantarelli, Per Stromberg, Sheridan Titman, Rob Vishny, an anonymous referee, René Stulz (the editor), and participants at seminars at a CEPR conference on "International Perspectives on the Macroeconomic and Microeconomic Implications of Financing Constraints," in Bergamo, the University of Chicago, the London Business School, the NBER, the WFA meetings, and the AEA meetings for useful comments. Andy Pruitt provided excellent research assistance. Research expenses have been supported by the Center for the Study of the Economy and the State. The author also acknowledges financial support from the Center for Research in Security Prices and the NSF grant \#SBR-9423645. Any opinions expressed are those of the author and not those of the National Bureau of Economic Research.

(C) 1997 by Luigi Zingales. All rights reserved. Short sections of text, not to exceed two paragraphs, may be quoted without explicit permission provided that full credit, including $\mathbb{C}$ notice, is given to the source. 
Survival of the Fittest or the Fattest? Exit and

Financing in the Trucking Industry

Luigi Zingales

NBER Working Paper No. 6273

November 1997

\begin{abstract}
This paper studies the impact that capital market imperfections have on the natural selection of the most efficient firms by estimating the effect of the pre-deregulation level of leverage on the survival of trucking firms after the Carter deregulation. Highly leveraged carriers are less likely to survive the deregulation shock, even after controlling for various measures of efficiency. This effect is stronger in the imperfectly competitive segment of the motor carrier industry. High debt seems to affect survival by curtailing investments and reducing the price per-ton-mile that a carrier can afford to charge after deregulation.
\end{abstract}

\title{
Luigi Zingales
}

Graduate School of Business

University of Chicago

1101 East 58th Street

Chicago, IL 60637

and NBER

luigi@gsblgz.uchicago.edu 
Most economic theories are either implicitly or explicitly based on an evolutionary argument: competition and exit assure that only the most efficient firms survive. This argument implicitly relies on the existence of perfect capital markets. In the presence of capital market imperfections, efficient firms may be forced to exit due to the lack of funds. Although this argument is well understood in theory (Telser (1966) and Bolton and Scharfstein (1990)), its empirical relevance is much less clear.

The crucial issue in trying to assess the effects of financing choices on the survival of firms and, thus, on the product market competition is the endogeneity of capital structure choices to the industry structure. If leverage affects firm's competitive position, then firm's financing decisions will take this into account. As a result, in the absence of a structural model we cannot determine whether it is the product market competition that affects capital structure choices or a firm's capital structure that affects its competitive position and its survival.

This paper attempts to address the endogeneity problem by looking at the effects of leverage on the survival of trucking firms after the Carter deregulation. Deregulation was an exogenous shock, which unexpectedly changed both the competitive environment in which firms operated and the leverage of firms, driving the effective leverage far away from the desired one. By decreasing the value of firms' operating certificates, a sort of monopoly license, deregulation sharply increased leverage above the desired level. Also, because deregulation increased the risk in the industry and made predation possible, it is likely that the target leverage decreased at the same time the firms' real leverage increased dramatically.

I study the survival of trucking companies during the eight years following the beginning of deregulation as a function of their economic efficiency (fitness) and their financial resources (fatness). I find evidence that more efficient firms are more likely to survive after deregulation, but I also find evidence that their leverage at the beginning of the deregulation period has an impact on the probability of survival 8 years later. Therefore, not only the "fittest" but also the "fattest" firms survive.

This result might appear obvious. It is well known that firms in a weak financial position are more likely to go bankrupt; this may be true independent of any effects of financing on the firm's competitive position. To address this issue, I try to control for the ex-ante risk of default 
by using Altman's (1973) Z-score method. Even after controlling for the ex ante probability of default, leverage has still negative and statistically significant impact on survival. I also show that this effect is not present in the early years after deregulation, but is concentrated in the 1980 to 1985 period, when the industry shake-out was more dramatic. Interestingly, this effect is not homogeneous across different segments of the industry. It is most pronounced in the segment that remains imperfectly competitive even after deregulation, and it is zero in the segment that becomes fully competitive.

I also try to probe deeper into the reasons why debt may jeopardize survival. In particular, I look at the investments undertaken by motor carriers after deregulation and their pricing policy as a function of their initial level of leverage.

I find that the initial level of leverage has a negative impact on the ability of a motor carrier to invest in the years following deregulation. The effect is particularly pronounced in those companies that are eventually forced to exit, suggesting that the underinvestment problem caused by the high debt level might have forced these firms out of the market.

I also find evidence that the pre-deregulation level of leverage negatively impacts the price per-ton-mile that a carrier charges during the price war which followed deregulation. This effect is entirely concentrated in the less competitive segment of the industry.

This paper is part of a growing literature on the interaction between capital structure and product market competition. Besides a very early article by Spence (1985), the pioneer works in this area are Phillips (1995) and Chevalier (1995a and 1995b). They study the effects of leverage on price competition and exit in industries that experienced a large number of leveraged buyouts (LBOs). Both find significant effects of the LBOs on the competitive environment, under the form of increased prices and increased exit. Similarly, Kovenock and Phillips (1997) use plant-level data to analyze the impact of a company's leverage on its plant closing decisions in industries where at least one of the major players undertook an LBO. They find that debt affects plant closing and investment decisions only in highly concentrated industries.

The interpretation of all these results, however, is made controversial by the fact that the decision to undertake an LBO is not necessarily exogenous with respect to the competitive 
environment in which a prospective LBO firm operates. If the managers of LBO firms anticipated the ultimate outcome of their actions, it would be impossible to distinguish whether these outcomes are the desired effects that LBOs tried to achieve in the first place or their unwanted side effects.

A step forward in addressing the endogeneity problem is represented by Chevalier and Scharfstein (1996). They look at supermarkets' profit margins during recessions in regional markets differentially affected by LBOs. To the extent that some major recessions (like the Texas oil shock) are unexpected or very unlikely ex ante and that these recessions change the very nature of the competitive environment, it is possible to interpret the results in a causal sense. A related paper studying the effects of liquidity constraint on survival by using an exogenous shock is also Holtz-Eakin, Jouflaian, and Rosen (1994). They study the impact of inheritance on the probability of survival of small entrepreneurial firms.

The rest of the paper proceeds as follows. Section I provides some background information on the characteristics of the trucking industry before and after deregulation. Section II describes the competing hypotheses on the effects of financial variables on the survival of firms and explains why the natural experiment represented by the trucking deregulation helps identify these effects. Section III introduces the reader to the new dataset used in this paper. Section IV presents the results on the determinants of survival. Section V discusses the possible sources of this effect. Finally, Section VI concludes.

\section{The Trucking Industry}

Interstate motor carriers were brought under federal regulation by the Motor Carrier Act of 1935, designed "to protect the public interest by maintaining an orderly and reliable transportation system, by minimizing duplications of services, and by reducing financial instability." The act exempted the trucking industry from the antitrust law and required all interstate motor carriers to file their rates with the Interstate Commerce Commissions (ICC), which had the authority to set minimum rates and suspend rate cuts. Similarly, the ICC had the power to regulate entry into the industry through the concession of operating certificates. The ICC followed a policy of not granting authority to serve a route already served so long as the 
existing carriers provided adequate service.

As a result of this regulation, rates were above marginal costs, as shown by the fact that the operating certificates were priced at 15-20 percent of carrier annual revenue (Breen (1977)). Besides the holders of the operating certificates, the other big beneficiaries of regulation were the unionized employees (International Brotherhood of Teamsters), who, according to Moore (1978), earned 30 percent more than similar workers in unregulated carriers.

The deregulation process began as a change in policy at the ICC level and was sanctioned by the passage of the Motor Carrier Act of 1980. The appointment of Daniel O' Neal as a chairman of the ICC in 1977 was instrumental to this change. A detailed chronology of the events and their impacts on the stock prices of publicly traded carriers is contained in Rose (1985) and Schipper, Thompson, and Weil (1987). In sum, between 1978 and 1979 the ICC reversed its policy towards entry, accepting well over 90 percent of new service applications and beginning to liberalize rate settings. The effect was a substantial drop in the stock market value of trucking companies and a reduction in the premium of unionized workers in the trucking industry (Rose (1987)).

The deregulation effects on the entire industry were devastating. Carriers started to compete on price. As the president of a Teamsters local viewed it, "the rate cutting is horrible. The shippers are pitting one trucking company against the other. I heard that one cut the rate 47 percent." 1 As a result of this new intense price competition, between 1980 and 1985 a total of 4,589 trucking companies across the nation shut down, compared to 1,050 that closed between 1975 and 1980 (a five-fold increase). ${ }^{2}$ At the same time the industry experienced a huge wave of new entries. The number of carriers at the end of 1983 was about 40 percent higher than the number that existed when the Motor Carrier Act went into effect. ${ }^{3}$ In many cases unionized trucking companies were closing to leave room for new, nonunionized companies.

There is no question, then, that the regulatory reform of the late 1970s changed the competitive environment of the trucking industry (see also Winston (1993)). However, there might be some question about how expected this event was when it took place. Had this event been perfectly anticipated, its effects would have already been reflected in the financing policy of trucking firms. Rose (1985) mentions that some initial steps for industry reform were taken 
by the ICC as early as 1975 , with the main activity taking place in the 1978-1979 period. In a subsequent paper, Rose (1987) adopts the convention of dating deregulation from 1979. From an analysis of the S\&P Industry Outlook of those years, I conclude that it is probably safe to take 1977 as the watershed. In that year, the industry report stated: "the industry will continue to be faced with the threat of regulatory reform. . . . However, given the strong opposition of the Teamsters' union, the successful lobbying campaign by the industry, and the opposition of the ICC, the materialization of any serious threat over the near term remains unlikely." The large decline in stock prices during the 1978 to 1980 period (see Rose (1985) and Schipper, Thompson and Weil (1987)) confirms that deregulation was largely unanticipated, and that deregulation hit the industry during that period.

In studying the trucking industry, it is important to keep in mind its division into two fairly different segments: the truckload (TL), with shipments of 10,000 pounds or more, and the less-than-truckload (LTL), with shipments less than 10,000 pounds. The TL segment is characterized by easy-to-finance capital investment and facility of market entry (in the absence of regulation). The LTL segment requires large capital investments to create hubs and generate a network able to distribute loads across different trucks, minimizing empty backhaul mileage. ${ }^{4}$

The competitive pressure was experienced differently in the two segments. According to Moore (1986), rates in the TL sector fell 25 percent from 1977 to 1982 . During the same period the LTL rates fell only 12 percent. The source of competition was also different. The TL segment suffered from both the entry of new carriers and the expansion of private carriers (businesses that haul their own products). By contrast, the LTL segment became quickly crowded with existing carriers that expanded in the LTL market as a way to refocus their operating strategy in the face of entry by non-unionized carriers in the TL market.

\section{The Competing Hypotheses}

\section{A The Theoretical Predictions}

This paper addresses two related questions. First, how does leverage affect a firm's ability to respond to unexpected changes in the competitive environment? Second, what are the sources 
of these effects? In this section, I briefly summarize what theory has to say about these two questions and how my "natural experiment" helps test these predictions.

If a firm's financial structure is irrelevant, then I should find no effects of the initial leverage on a firm's ability to survive, provided I can properly control for a firm's efficiency level. Otherwise, there are three main reasons why the pre-deregulation level of leverage may negatively impact a motor carrier's survival during deregulation.

First, the initial level of debt may negatively affect survival because highly indebted firms may be unable to finance large new investments (Myers (1977)). This debt overhang might force leveraged firms to pass up profitable growth opportunities and, in the most extreme cases, even force them out of the market. As Myers (1977) points out, this problem is more likely to arise when investments cannot be collateralized easily. Therefore, debt overhang should not in general be a very serious problem for TL trucking companies, which have easy-to-collateralize assets. LTL carriers, however, might suffer more, because a larger fraction of their assets is intangible.

Second, the initial level of debt may negatively affect survival because it directly affects a firm's ability to compete. For example, in Bolton and Scharfstein (1990), shallow-pocket firms are prone to predation by deep-pocket competitors. This predation may force highly leveraged firms to lose their market share or even exit the industry. This effect should be present only in less competitive industries, because only in the presence of some barriers to entry can the predator recover the short-run costs of preying in the long run. Alternatively, a high level of leverage may affect a firm's competitiveness because customers avoid dealing with a company that is likely to go bankrupt (Titman (1984)), or because the leverage affects a firm's incentive to maintain its reputation for producing a high quality product (Maksimovic and Titman (1991)). All of these effects should be unimportant for TL carriers, which provide a standardized service, but they may be relevant for LTL companies.

Finally, the initial level of debt may negatively affect survival, because it forces inefficient firms to liquidate (Harris and Raviv (1990) and Stulz (1990)). Note that, unlike the two previous examples, here a negative correlation between survival and leverage is not evidence of a cost, but of a benefit of debt. The costs of liquidating a TL versus an LTL carrier are 
likely to be very different. Most of TL carriers' assets are represented by trucks, which can be liquidated at no significant cost. By contrast, part of the value of an LTL carrier comes from its terminal network and its sales organization, which are more costly to liquidate. As a result, it is plausible that the reduction in profitability produced by deregulation makes it optimal to liquidate more TL carriers than LTL ones. It follows, then, that debt should have a stronger negative impact on survival of TL carriers, rather than LTL ones.

On the other hand, there are two main reasons why the pre-deregulation level of leverage may positively impact a motor carrier's survival during deregulation.

First, debt might force firms into restructuring sooner (Jensen (1989)), maximizing their chances of survival. This might be particularly true in the trucking industry, where one of the biggest problems of existing firms was to convince unionized workers to accept wage cuts. For example, Perotti and Spier (1993) have modeled the benefits of debt in extracting wage concessions from unions. If this is the case, then highly indebted carriers should be able to address their wage bargaining problems sooner and more effectively and, by so doing, should be more likely to survive. Since the TL market is more likely to be nonunion and pay competitive wages (through purchased transportation agreements), this effect is likely to be more pronounced in the LTL sector.

Second, a highly leveraged firm may compete more aggressively because of the option-like payoff of leveraged equity (Brander and Lewis (1986)). If ex-post an aggressive expansion turned out to be the winning strategy, then I should find that more highly leveraged firms are more likely to survive in the post deregulation period. This argument should apply mainly to the LTL segment of the industry because of its less competitive structure.

\section{B The Nature of the Experiment}

As it is well known, any attempt to investigate the effects of financial variables on real variables is affected by two econometrics problems. First, capital structure choices are endogenous and, in the absence of an accepted structural model, we cannot determine whether, for instance, it is the product market competition that affects capital structure choices or rather the firms' capital structure that affects their competitive position and, eventually, their survival. Second, 
an econometrician can only observe imperfect proxies of the firm's characteristics that determine its capital structure and its performance. As a result, a correlation between the initial financial position and the probability of exit may arise even if there is no causal relationship between the two, simply because both a company's debt level and its survival are affected by the same company's characteristics that are unobservable to the econometrician.

The "natural experiment" provided by the trucking deregulation helps address the first problem in several ways. First, motor carriers' deregulation brought a major and unexpected change in the competitive structure of the trucking industry. During the regulated period firms had been barred from price competition and isolated from new entry; but beginning in 1979 they suddenly faced intense price competition and massive new entry. This change in the competitive environment is exogenous with respect to trucking firms' leverage and their performance. ${ }^{5}$ Since this exogenous change in the competitive environment was largely unexpected, it is difficult to argue that the capital structure was optimally chosen beforehand to deal with it. As a result, I can try to separate the undesired effects of debt from the desired ones by estimating the effect of debt on exit after controlling for the expected defaults under the pre-existing conditions.

Second, not only did deregulation change the product market environment, but it directly affected firms' capital structure. In fact, a significant portion of a motor carrier's assets was represented by the value of the operating certificates. In many cases, these were also used as a collateral for bank loans. I have estimated that in the 1977 to 1980 period the marketto-book value ratio of assets of publicly traded trucking firms dropped by 20 percent. This translates into a sudden and unwanted increase in the effective level of leverage. As a result, it is likely that motor carriers found themselves excessively leveraged. This is especially true if one considers the increased uncertainty that followed deregulation.

Third, the nature of the sample makes it very unlikely that companies could promptly adjust their capital structure to the deregulation shock. In fact, most of the firms in my sample are small privately held firms with little or no access to the public equity or bond markets. This makes it harder for them to quickly readjust the leverage after a negative shock such as the loss of the operating rights value and the change in the competitive environment. 
The natural experiment of deregulation, though, does not resolve by itself the second problem: the possibility of spurious correlation due to unobservable characteristics. I address this problem in three ways. First, I address it directly, by using a wide variety of control variables that should help capture all firms' characteristics. Second, I look for evidence of the mechanism by which an excessive amount of debt forces exit. In particular, I focus on its effect on investment and on pricing. Third, I divide the sample according to a carrrier's percentage of LTL revenues and estimate the impact of debt across different groups. Since the theories discussed above suggest that debt has different impact for high and low LTL carriers, in a linear probability model I can use this splitting as an instrumental variable. ${ }^{6}$ In this way, my estimate of the differential effect of debt on survival across groups is consistent even if there are unobservable firm characteristics correlated with leverage.

\section{The Data}

As a consequence of the Motor Carrier Act of 1935, each regulated motor carrier holding interstate operating authority is required to file a calendar year report. In this report, trucking companies have to disclose not only financial variables but also operating statistics, like the number of shipments made, the total number of ton-miles hauled, etc. The level of disclosure depends on the size of the carriers. Before 1980, carriers with gross revenue above $\$ 500,000$ (Class I and Class II) filed comprehensive reports, including operating statistics, while carriers with gross annual revenues below $\$ 500,000$ (Class III) had to file brief statements, if their revenues exceeded $\$ 100,000$. In 1980 , the minimum threshold for class II carriers was increased to $\$ 1,000,000$ and Class III carriers were released from filing. The data used for this paper comes from the American Trucking Association, which has been collecting and reclassifying ICC filings since 1976.

To determine the survival after deregulation, I have to establish when the deregulation shock hit the industry, and when the transition to a more competitive industry can be considered to be accomplished. On the basis of the stock price evidence and of the industry report I identify three periods: the pre-1978 years can be considered a fully regulated period, 1978 to 1980 represents a transition period, and the post-1980 years represent the deregulation 
period. By reviewing the S\&P Industry Outlooks for every year since 1977, I decided that the industry transition was complete by 1985. The 1982 to 1983 recession hit the trucking industry particularly hard, and caused enormous exits. However, by 1984 to 1985 profits and rates in the industry became more stable. This can be considered as the first period in which the industry returned "back to normal."

Thus, my dataset consists of all ICC filings collected by the ATA for the period 1976 to 1985. As a result of the higher threshold for disclosure and the reduction in Class I and Class II carriers following deregulation, the number of carriers in the dataset drops from 2,897 in 1976 to 1,922 in 1985 .

The ICC divides carriers into 13 categories as a function of the goods hauled: from general freight to household goods, from package (courier) to bulk commodities, etc. These categories can be thought of as different market segments. Specialized commodity carriers, for example, use different trucks, which cannot be easily adapted to carry general freight. As Table I shows, general freight carriers are by far the largest group (41 percent of the carriers). They are required to disclose more detailed information than specialized carriers. For both these reasons, I restrict my analysis only to this segment of the market. This guarantees greater homogeneity within the sample used, and greater availability of data.

\section{A Definition of Exit}

For the purpose of this study it is important to understand how I measure exit. I consider that a firm exits when it disappears from the ATA dataset. Trucking firms keep reporting to the ICC even if they are acquired, as long as they are separately operated. Each one has its own identification number, so name changes should have no impact. As a result, firms disappear from the dataset if they are liquidated (both voluntary liquidation and bankruptcy) or if they are acquired and merged with the acquiring firm. Therefore, by using the disappearance from the ATA dataset as an indication of exit, I measure the survival of a trucking company as a separate organization.

During the post-deregulation period exit took place not only through bankruptcy, but also through voluntary liquidation. ICC reports show that, during the 1979 to 1985 period, 1,328 
Class I, II, and III interstate motor carriers ceased operations for "legal, personal, economic or labor reasons," not involving bankruptcy. ${ }^{7}$ Although the different ways in which firms exit from a market is also an interesting subject, the objective of this paper is to test whether the most efficient organizations survived, regardless of the way they were financed. The measure I obtained seems appropriate for this scope.

Firms exit from my dataset also because they fall below the minimum level of revenues that mandates disclosure (500,000 up to 1979 , one million afterward). Although a significant drop in revenues can be regarded as an indication of failure in the marketplace, I do not want to consider as exited the firms that have a temporary drop in sales. For this reason, I classify a carrier as exited in year $t$ only if it is not present in the dataset in that year and does not appear in any subsequent year, up to and including 1985.

Furthermore, to reduce this problem and to try to eliminate the bias induced by the change in disclosure requirements during the sample period, I restrict my analysis to companies having at least one million in revenues in 1977. Note that, given the high level of inflation in those years, a carrier with one million in revenues in 1977 will easily qualify as a class II carrier in 1980 even with a significant drop in real revenues. ${ }^{8}$

\section{B Summary Statistics}

Table II presents summary statistics for Class I and II general freight carriers with more than one million in revenues in 1977. In that year there were 941 firms satisfying these criteria.

A particularly detailed level of disclosure is requested of the so-called Instruction 27 carriers. These are carriers that derive on average 75 percent or more of their revenues from the intercity transportation of general commodities (approximately 60 percent of general freight carriers). Information for total ton-miles hauled, number of shipments made and percentage of shipments of more or less than 10,000 pounds tends to be present only for these carriers. Therefore, whenever I use this information, I lose 20 to 30 percent of the observations.

As pre-deregulation level of all the variables I use the average of the 1976 and 1977 values. The extremely high return on assets (ROA), equal to 18 percent, can be viewed as a sign of the rents enjoyed by trucking companies during the regulation era. Similarly, return on sales 
(ROS) is 8 percent. Another effect of regulation is the high value of intangibles as a fraction of assets (6 percent). Operating certificates bought from other carriers are included under this category. This is only a rough estimate of the true value of operating certificates, because only the certificates recently acquired (through a direct purchase or a merger) are valued fully.

Leverage measured as total debt divided by total debt plus book equity is 40 percent (median 35 percent). By subtracting cash reserves from the total debt, the mean leverage becomes 22 percent (median 20 percent). It is difficult to judge whether these are high or low levels of leverage, because very little is known about the capital structure of privately held companies (as most of these are). What makes the comparison even harder is that firms are required to file with the ICC on a nonconsolidated basis. As a benchmark, I collected data for the 66 trucking firms present in Compustat in 1977 (SIC codes 4210 to 4213). For these firms the ratio of debt to capital is 44 percent, not very different from the ICC sample.

The book value of leverage probably overestimates the actual leverage before deregulation, because the book value of equity does not include the market value of monopoly profits (except for the recently traded operating certificates). A more appropriate measure of actual leverage before deregulation is provided by the level of coverage (earnings before interest, taxes, and depreciation over interest expenses). ${ }^{9}$ A median coverage of 9.8 gives a sense of the rather healthy financial conditions of the trucking industry before deregulation. The book leverage, however, is probably a good estimate of the market leverage after deregulation, when operating certificate became worthless.

During the 1977 to 1985 period 57 percent of general freight carriers with more than one million in revenues exited the industry. Of those, 22 percent exited in the 1977 to 1980 period, while 35 percent exited between 1980 and 1985 .

While the trucking industry did not grow very much during the period, surviving trucking companies experienced substantial growth during both sub-periods. For carriers surviving up to 1980 the average rate of nominal growth in revenues during the 1977-1980 period is 40 percent. The same rate during the $1980-1985$ period for carriers surviving up to 1985 is 92 percent. 


\section{The TL versus LTL Distinction}

In the following analysis, an important role is played by the distinction between TL carriers and LTL carriers. Ideally, we would like to compare "pure" TL carriers with "pure" LTL carriers. As the summary statistics indicate, however, there is no such clear-cut distinction. In 1977 , most carriers hauled both truck loads and less-than-truck loads, and on average 58 percent of general-freight carrier revenues came from LTL shipments.

To try to disentangle the differential effects of leverage in these two different segments of the market, I create three groups: carriers with less than 30 percent of their revenues in LTL, carriers with between 30 percent and 70 percent in LTL, and carriers with more than 70 percent in LTL. In 1977, among those carriers that reported information about their revenues per class of weight, there are 113 carriers in the first group, 266 in the second, and 270 in the third. The attrition rate is identical in the two extreme groups (59 percent), it is slightly higher in the middle one ( 67 percent).

\section{Ex Ante Differences Between Survivors and Non-Survivors}

Before turning to a multivariate analysis, it is interesting to analyze the ex ante differences in financial and operating characteristics of carriers as a function of their fate in 1985 . This is done in the sixth and seventh columns of Table II.

Survivors tend to be larger firms, with higher profitability and lower leverage. In particular, the 1977 return on sales of future survivors is 4 percentage points higher, while ROA is 7 percentage points higher. This result suggests that deregulation did, on average, select more efficient firms. This finding is confirmed by cost per mile ( 9 cents per ton-mile lower for survivors), although this difference is not statistically significant at conventional levels. Quite surprisingly, survivors tend to have lower revenues $(3$ cents) per ton-mile. This might be an effect of the fact that carriers who used to enjoy large monopoly rents are less likely to survive. The same effect is observed in the fraction of intangibles: survivors have on average 1 percent fewer assets represented by intangibles. If the value of operating certificates reflected in intangibles is an indication of the degree of monopoly enjoyed by a certain carrier in its routes, this fact suggests that survivors are firms that enjoyed lower monopoly rents during 
the regulation era. It is remarkable how much lower was the 1977 level of levarage of firms who survived. The median ratio of debt over debt plus equity for survivors is 0.30 , while for non survivors is 0.41 . The difference is similar when I subtract cash reserves: 0.13 versus $0.27 .{ }^{10}$

Motor carriers can differ substantially in their cost structure. While some carriers rely mostly on employees for their shipments, others contract out a significant amount of transportation services. Contracting out transportation services was often used to prevent the unionization of the workforce.

The proportion of wage and benefits over total operating expenses captures these differences in cost and degree of unionization, because transportation services contracted out are recorded as purchased transportation and, thus, reduces the fraction of reported labor cost over operating expenses. Interestingly, survivors have a significantly smaller percentage of their operating costs accounted for by wages.

By contrast, there is no statistically significant difference between the average haul and the average load of survivors versus non survivors. Similarly, the percentage of LTL revenue is not significantly different for survivors.

\section{The Effect of Leverage on Survival}

The first question I want to answer empirically is whether initial leverage has any effect on the firm's probability of surviving, beyond what efficiency considerations would suggest. In a perfect capital market world the survival and the growth of a firm should be entirely determined by its efficiency characteristics. Therefore, the null hypothesis is

$$
\operatorname{Pr}\{\text { survival in } 1985\}_{i}=f\left(X_{i}^{1985}\right)+v_{i}
$$

where $X_{i}$ is a measure of firm $i$ 's efficiency. Unfortunately, $X_{i}^{1985}$ is not observable for the firms that exited. Even if it was, I would not necessarily want to use it because the observed level of efficiency might be affected by the preexisting level of leverage. However, I can use some ex ante efficiency measures as a proxy for a motor carrier level of expected efficiency in the absence of any real impact of financial variables. In other words, I use $X_{i}^{1977}$ as a proxy 
for $X_{i}^{1985}$.

This substitution corresponds to the assumption that the pre-deregulation level of efficiency is linked to the post deregulation one. As long as surviving companies are concerned, this assumption is supported by the data (for instance the level of ROS in 1985 is statistically and economically significantly related to the level of ROS in 1977). Nevertheless, one potential concern is that the preexisting level of leverage is correlated to some unobservable characteristics that determine future efficiency. In what follows, I present a series of proxies designed to address this concern.

In sum, the basic regression relates a firm's status in 1985 to financial and operating variables in 1977 , or

$$
\operatorname{Pr}\{\text { survival in } 1985\}_{i}=f\left(X_{i}^{1977}, \operatorname{Lev}_{i}^{1977}\right)+\epsilon_{i},
$$

where $L e v_{i}$ is a measure of financial leverage.

Table III presents the results of estimating equation (2) through a probit model. For ease of interpretation, I report the coefficients as the derivative of the probability of survival with respect to the corresponding right hand side variable computed at the mean of the dependent variable. This represents the marginal impact of a change in the explanatory variable.

In the basic specification - besides leverage - the explanatory variables are: return on sales, a company's size (logarithm of the level of the average sales in 1976 and 1977), the level of intangibles (as a fraction of total assets), the proportion of wages over total costs, and nine regional dummies.

Return on sales is chosen as a main measure of efficiency for two reasons. It is directly related to the operating ratio (operating expenses over operating revenues), which is the leading efficiency index used in the trucking industry. Second, it is less sensitive than return on assets to misvaluation of assets or to the extent to which some transportation is done with "for hire" trucks.

A measure of size is inserted for various reasons. Size might be a proxy for efficiency, because only efficient firms become big. ${ }^{11}$ Larger firms may also have more bargaining power on the product market and/or have easier access to financing. Finally, size may matter for 
spurious reasons, because small firms are more likely to fall below the threshold that requires them to file with the ICC. All these explanations predict a positive impact of size on the chances of survival.

I insert the level of intangible assets as a proxy for the extent to which a carrier enjoyed monopoly rents before deregulation. This is admittedly a poor proxy, because only recently acquired operating certificates appear in the balance sheet. ${ }^{12}$ It is important, though, to attempt to control for monopoly rents before deregulation because the measure of efficiency used (return on sales) is distorted by the presence of monopoly rents. For a given level of profitability, a higher degree of monopoly indicates that a firm is less efficient. The level of intangibles, then, is expected to have a negative effect on survival.

A high proportion of wage and benefits over total operating expenses reflects a limited role of purchased transportation and/or a more expensive labor force. Since both these phenomena are generally associated with unionization, a high proportion of wage and benefits can also be interpreted as a proxy for unionization. All these factors are likely to have a negative impact on a firm's ability to survive in a deregulated environment.

Finally, regional dummies are inserted to control for possible heterogeneity across different areas. Carriers are attributed to one of the nine geographical groups established by the ICC on the basis of a carrier's main location.

As expected, more profitable firms are more likely to survive, and so are larger firms. By contrast, firms with a higher proportion of labor cost over total cost are less likely to survive. All these effects are statistically significant at the 5 percent level or less. Even after controlling for these variables the initial level of debt seems to jeopardize a firm's chances of survival. The effect is statistically significant at the 1 percent level and is also economically relevant, although not huge. A one-standard deviation increase in leverage reduces the probability of survival by 8 percent.

An alternative way to measure the economic importance of this effect is by answering the following question: how much more efficient (i.e. profitable) must a company be to offset the negative impact on survival produced by an increase in leverage from 0.2 (the average) to 0.3 ? By using the probit estimates, I obtain that a trucking company needs to have a return on 
sales 0.7 percentage points higher (i.e., 10 percent higher with respect to the median ROS of 7 percent) in order to offset 10 percent more capital financed by debt. The effect, thus, is small but not trivial.

The impact of leverage remains unchanged when I use return on assets (ROA) rather than return on sales as a measure of a firm's efficiency (see column II). Similarly, results are not substantially changed if other measures of leverage are used. For example, specification III uses coverage instead of net debt to capital, with similar results.

\section{A Alternative Measures of Efficiency}

Using return on sales (or on assets) as a measure of efficiency can pose some problems. First, given that in 1977 the trucking industry was regulated, a high return on sales may just indicate the presence of large monopoly rents, not a high degree of efficiency. Second, high return on sales is also associated with a greater availability of cash flow from operations, and ROS may also capture this additional effect.

In order to test the robustness of my findings, I try some alternative measures of efficiency. The first is an estimate of the distance of each motor carrier from the production possibility frontier. This is a measure of technical inefficiency, which does not rely on any assumption on the market in which a firm operates. As described in the Appendix, I estimate this by following the technique suggested by Schmidt and Sickels (1984).

The results are reported in the first column of Table IV. The degree of inefficiency has a positive (and not negative) effect on the probability of survival, and this effect is borderline statistically significant. ${ }^{13}$ However, it is interesting to notice that the impact of leverage on the probability of survival remains unchanged after introducing this additional measure of efficiency.

Another measure of efficiency is the cost of operations. For the carriers that disclose the number of ton-miles hauled, I can obtain a measure of the cost per ton-mile. This measure has the advantage of being independent of the market structure in which a carrier operates. Regardless of the size of monopoly rents, a trucking company should always minimize costs. This measure has the drawback that it improperly accounts for a firm's cost of capital. In 
fact, operating expenses include depreciation (accounting, not economic, depreciation) and do not include the opportunity cost of capital. Another disadvantage is the fact that cost per ton-miles does not control for differences in the traffic mix (i.e., different average hauls and different average length of hauls).

The second column of Table IV reports the results of the previous probit model, when cost per ton-mile is inserted as an additional measure of efficiency. Notice that, because of data limitation, the number of observations available drops by 25 percent with respect to Table III. Higher cost carriers are not at all less likely to survive after deregulation than low cost carriers. Again, the impact of leverage is still present and statistically significant.

Finally, a last attempt to control for the expected efficiency of motor carriers after deregulation is done in column III, by using the return on sales in 1980 . I use 1980 because it is a watershed year. While the major changes in the trucking industry took place in the 1980 to 1985 period, the ICC deregulation started in 1978. Therefore, the 1980 ROS should at least partially capture the after deregulation efficiency level, while leaving enough observations of exit.

Column III in Table IV shows that the results are not substantially changed when I disregard 1978 to 1980 exits and insert the 1980 ROS as an additional explanatory variable. This suggests that 1977 leverage is not simply a proxy for an unobserved efficiency factor. ${ }^{14}$

\section{B Controlling for the Ex Ante Risk of Default}

It is possible that the most highly leveraged firms in 1977 were also the most inefficient and, thus, the most likely to exit the industry independent of any negative effect of debt. In the event that my measures of efficiency do not fully capture a firm's quality, the observed effect of leverage may simply be a spurious one.

To address this problem I try to control for the ex ante probability of default. I do that by using Altman's Z-score method. Altman (1968) is the first to develop a discriminant analysis method to forecast the probability of a firm's default using accounting information. One of the many applications of Altman's method is to the railroad industry, Altman (1973). Given the similarities of the regulatory environment and of the accounting disclosure between the 
railroad and trucking industry, I choose to use the estimates of the Z-score model derived in this context. ${ }^{15}$ Each firm is assigned a score according to the following formula in Altman (1973):

$$
Z=0.2003 X_{1}-0.2070 X_{2}+0.0059 X_{3}+0.1040 X_{4}+0.0885 X_{6}+0.0688 X_{7}
$$

where $X_{1}$ is cash flow over fixed charges, $X_{2}$ is transportation expenses over operating revenues, $X_{3}$ is earned surplus over total assets, $X_{4}$ is the 1-year growth rate in operating revenues ${ }^{16}$, $X_{5}$ is earnings after taxes over operating revenues, $X_{6}$ is operating expenses over operating revenues, and $X_{7}$ is income before interest and taxes over total assets. The higher the Z-score, the lower the probability of default is.

Table V, column I, reports the estimates of the basic regression after having inserted a carrier Z-score as a proxy for the ex-ante probability of exit. As expected, companies with a higher Z-score are more likely to survive. Nevertheless, the initial leverage has still a negative and statistically significant impact on the chances of survival, and its magnitude is substantially unchanged.

I can also use the Z-score to separate the desired effect of debt on exit from the undesired one. Suppose that the pre-deregulation level of leverage was chosen to induce the optimal liquidation policy of motor carriers in the pre-deregulation environment. Then, the pre-deregulation Z-score should capture the desired effect of debt on exit and any residual effect can be interpreted as the undesired effect. Therefore, I want to estimate the effect of debt conditioned on the fact that the $\mathrm{Z}$-score method predicted survival.

To transform the Z-score into a prediction on a firm's default I need to choose a cut-off point. If I use Altman's cut-off point, I obtain very few defaults and the results are substantially identical to the one reported in Table III. Therefore, I choose the cut-off point so that the number of predicted defaults corresponds to the number of actual exits from my sample. Note that by doing so I bias the results against finding any effect of debt. In fact, ex ante people did not expect such a large exit from the trucking industry.

Table V, column II, reports the estimates of the basic regression restricted to the firms that the Z-score method predicts would survive. The initial level of leverage still has a negative im- 
pact on survival, and this impact is statistically significant at the 1 percent level. Profitability and size have coefficients similar to the basic estimates and are both statistically significant at the 1 percent level. This negative effect of debt can be interpreted as the undesired effect of debt on survival.

For completeness, I also report the estimates conditioned on the Z-score model predicting a default (Table V, column III). Again leverage has a negative impact on the probability of survival, statistically significant at the 5 percent. All the other variables have the same sign, and all except the ratio of intangible assets are significant at the 10 percent level or better.

\section{Comparison of Leverage and Its Effects in the TL and LTL Segment}

Table VI, panels A, B, and C report summary statistics for carriers in the different segments of the market. LTL carriers tend to be larger, in terms both of sales and of assets, and to be less highly levered. Interestingly, there is no difference in the initial level of debt between survivors and non survivors among TL carriers, while this difference is large and statistically significant for carriers with at least 30 percent of revenues in LTL and for carriers with more than 70 percent of revenues in LTL (see last two columns of Table VI).

This differential impact of leverage, however, does not control for the different characteristics of the carriers in the three segments. This is done in Table VII, which reports the estimates of equation (2) for the three segments. Interestingly, the initial level of debt has no impact on the probability of survival of motor carriers with less than 30 percent of their revenues in LTL. The point estimate is actually positive (0.02), albeit not statistically significant. By contrast, the initial level of debt has a strong and statistically significant negative effect on survival in the other two groups, more heavily involved in LTL. In particular, the impact of debt on survival of the carriers most concentrated in LTL is statistically different (at the 10 percent level) from the impact of debt on survival of the carriers least concentrated in LTL.

In an unreported regression, I also estimate the effect of debt on survival across the three groups using a linear probability model. As discussed in section II.B, in a linear framework the estimated difference in the impact of debt in the high LTL carriers and in the low LTL carriers is a consistent estimate of the true difference. The estimated difference is -0.26 , which 
is statistically different from zero at the 10 percent level. Thus, consistent with the theories predicting a negative effect of debt, this effect is larger (in absolute value) for predominantly LTL carriers. This finding also supports the view that the impact of debt on survival is not simply an effect of unobserved quality differences.

It is important to notice that these results arise in spite of the fact that the percentage of exits in the two extreme groups is the same. This fact makes the assumption that these results are driven by an unobserved firm characteristic that affects both leverage and exit implausible.

\section{Why Does Debt Affect Survival?}

The findings thus far suggest that the initial level of debt might have some consequences on the ability of a motor carrier to survive during deregulation. In this section, I try to uncover the sources of this observed relationship.

\section{A Investment}

If highly leveraged motor carriers are weeded out because they cannot successfully finance new investment, then I should be able to find some effects of initial leverage on the amount of investment undertaken by each firm during the post-deregulation period.

Since the ATA data set does not contain flow of funds data, I measure the total amount of capital expenditures in the post-deregulation period as the difference in gross operating property over the period 1977 to 1985 divided by the 1977 level of net operating property. I then estimate a reduced form equation in which investments are a function of a company's profitability, its size, the level of intangibles, and the proportion of labor cost.

Table VIII reports the OLS estimates of this equation. After controlling for the likely determinants of investments, the initial level of leverage seems to have no impact on the amount of investment actually made during the post-deregulation period.

One caveat, however, is warranted. If debt affects a firm's investment policy, the negative efficiency consequences of this underinvestment are likely to jeopardize a firm's ability to survive. Since we can observe the investment over a certain period only for the firms that survived until the end of the period, by estimating the investment over the entire post deregu- 
lation period I may miss the most important effect. To overcome this problem, I estimate the same investment equation considering only the investments that took place up to 1980 . By that time the deregulation shock on leverage has already occurred, but the large exodus from the industry has not.

The results are reported in the second column of Table VIII. In this case we do observe a negative effect of leverage on investment. One standard deviation increase in the initial level of leverage decreases the total investment in the three years following deregulation by 10 percent, and this effect is statistically significant at the 5 percent level.

If the proposed explanation is indeed the source of these ambivalent results, then I should find that the effect of debt on investments is mostly concentrated among firms that eventually exit the industry. The last two columns of Table VIII show that this is indeed the case. The investment policy of firms that eventually survive is not very much affected by debt. By contrast, this effect is very strong (both economically and statistically) among firms that exit the industry.

Why is the effect of debt mostly limited to firms that eventually exited? One possible explanation is that the market had different perceptions of the long term viability of highly leveraged carriers. Some were perceived as viable, obtained financing, invested as much as the low leveraged carriers, and survived. Others, which were not perceived as viable, were forced to curtail their investments and eventually left the industry. This explanation is consistent with Lang, Ofek, and Stulz (1996), who find that debt reduces the growth of firms with a low Tobin's $q$, but not of firms with a high Tobin's q. In fact, if one interprets survival ex-post as a proxy for the ex-ante Tobin's q (which I cannot observe because the firms are privately-held), my results are analogous to Lang, Ofek, and Stulz (1996). While this interpretation is consistent with some unobserved heterogeneity, it does not necessarily imply that non surviving carriers were of inferior quality. As Lang, Ofek, and Stulz (1996) point out, it might just be that they were perceived by the market as such.

Another (related) possibility, which does not rely on the surviving carriers being of a higher quality, is that highly leveraged firms differ in the resources available to their owners. Some firms may be owned by deep pockets investors, ready to support the necessary financing. 
These highly leveraged carriers, then, invest as the low leveraged ones and survive. By contrast, highly leveraged carriers without a deep-pocket investor cannot keep-up the investment level and, as a result, are forced to exit eventually.

In sum, the evidence suggests that the firms that exited the industry have suffered from an underinvestment problem linked to their initial level of debt. Yet, I cannot rule out the possibility that this effect is caused by unobserved heterogeneity in carriers' quality.

\section{B Pricing}

Leverage may affect survival also by weakening a firm's competitive position. As reviewed in section II, several models suggest that a high leverage may force firms into cutting their prices. These models, however, differ substantially in the nature of their predictions. Bolton and Scharfstein's (1990) model of predation makes predictions on the equilibrium price prevailing in a certain market as a function of the incentive of deep pocket firms to prey their shallow pocket competitors. By contrast, Titman (1984) and Maksimovic and Titman (1990) do not make any prediction on the market equilibrium price but only on the price differential between a firm and its competitors.

\section{B.1 Price data}

General freight carriers are required to disclose the amount of ton-miles transported in a calendar year. By dividing a carrier's operating revenues by the number of ton-miles reported, I can thus obtain a proxy of the actual price per ton-mile charged by each carrier. This measure is noisy because the price changes not only as a function of the segment of the market a carrier is in (TL versus LTL), but also as a function of the average haul of a carrier, since there is a fixed cost for loading and unloading each shipment.

However, if the composition of shipments of each individual carrier is fairly stable over time (a non trivial assumption during deregulation), I can eliminate some of the noise by considering the changes in the prices charged by the same carriers over a certain period. Therefore, I will use these estimated price changes over different time interval to analyze the effects of the initial level of leverage on a carrier's pricing policy. 


\section{B.2 Estimates of the impact of leverage on prices}

To test the predation hypothesis I would need to identify many separate markets. Unfortunately, I lack a clear way to do that. If I use the nine geographical regions identified by the ICC, I will have too few observations to estimate a cross-market regression. Using the state boundaries would give me more observations, but it is highly unsatisfactory from an economic point of view. There is no reason why the effective market in which a carrier competes is limited to the state in which its headquarter is located. To make things worse, the results would be very sensitive to the way a market is defined (and, thus, who the main competitors in this market are). Thus, I cannot test the predation hypothesis with the available data.

By contrast, I am better positioned to test the effect of leverage on the prices of individual carriers. While it would certainly be better to be able to control for factors that affect prices at a local-market level, the lack of a precise definition of market only weakens the power of the test.

For this reason, I try to explain changes in the prices charged by individual carriers as a function of some real variables and the initial level of leverage. The control variables are: first, state dummies, which absorb any regional effect; second, the proportion of labor cost over total cost at the beginning of the period, as a proxy of the cost structure of each carrier and, indirectly of its degree of unionization; third, the size of the carriers vis-à-vis its state competitors in 1977 (which I improperly refer to as market share), fourth, the percentage of revenues obtained through LTL shipments.

Table IX reports OLS estimates obtained from regressing the changes in the price charged by each carrier on these controlling variables and the initial leverage. I estimate separate equations for every year from 1980 to 1985 . The rate setting was liberalized in 1980 , so this year marks the beginning of price competition. On the other hand, 1985 can be considered the year when the post-deregulation industry equilibrium was reached. In between, 1982 represents the trough of a recession when, according to industry sources, price cuts were most aggressive.

Interestingly, in 1980 the price changes are unaffected by the initial level of debt: the coefficient is actually positive, but is economically and statistically indistinguishable from zero. It is only starting with 1982 , that the carriers that entered the deregulation period with 
more leverage start to charge significantly lower prices than their direct competitors. This effect is both economically and statistically significant. One standard deviation increase in the initial level of leverage decreases a carrier's prices by 7 cents per ton-mile. This represents approximately a 22 percent discount with respect to the average price per ton-mile. This effect persists in 1983 and 1984, while it is economically weaker and not statistically significant in 1985.

These results seem to support the idea that more highly leveraged firms are forced to discount their products, especially during recessions. It is less clear, though, what the ultimate reason for this discount is. It might be the fact that highly leveraged carriers are desperate for cash, or that consumers require a compensation for the risk of dealing with a company that might go bankrupt (Titman (1984)). While the first effect should hold indifferently across TL and LTL carriers, the second one is more likely to be important in LTL carriers which deliver a non-standardized product, where service is more important. It is worth noting that at the time there was much discussion in the press about the potential cost a LTL shipper might incur if its carrier defaulted in the middle of an important shipment.

For this reason, I explore the differences in the impact of debt across industry segments. To present these results in a concise form, I pool the price changes over the six-year period and estimate a separate coefficient of the initial level of debt for every year (the results are substantially identical if I estimate six separate regressions). Year dummies (not reported) are also inserted. Table $\mathrm{X}$ reports the results. Interestingly, the initial level of debt has no effect in the price changes of "pure" TL carriers. By contrast, the effect is very pronounced for the "pure" LTL carriers. It starts to manifest itself in 1981 and is particularly pronounced in 1982 and 1983. This finding is consistent with the hypothesis that leveraged carriers discount their services to compensate consumers for the risk associated with the probability of default of the carrier.

These results seem to contrast with Phillips (1995) and Chevalier (1995b), who find a positive relation between the increase in leverage caused by LBOs and increases in prices. The contrast, however, is more apparent than real. In fact, the industries studied by Phillips (gypsum, polyethylene, fiberglass insulation, and tractor trailer) and Chevalier (supermarkets) 
do not involve much specific investment by the customers. Thus, the need to discount the good in order to compensate the customers from the risk of bankruptcy, which is present for LTL carriers, is not likely to arise for their firms.

Moreover, neither paper finds that prices always increase. Phillips (1995) finds that, in one of the four industries he analyzes, prices drop after the LBOs. Similarly, Chevalier (1995b) finds that, in some local markets, supermarket prices drop after the LBO wave. In both cases, the authors point out that this phenomenon occurs in markets where there are some competitors with deep pockets. This is certainly the case in the trucking industry, if I consider that carriers are competing throughout the nation. In sum, the relation between prices and leverage seems to be very dependent upon the nature of the good and the financial position of competitors.

\section{Conclusions}

This paper studies the impact of capital market imperfections on the survival of firms. In general, the feasibility of such a study is seriously impaired by an endogeneity problem. It is impossible to determine whether firms perform poorly and exit because they are highly leveraged, or vice versa, that they are highly leveraged because they perform poorly and should be induced to leave. The deregulation in the trucking industry provides a unique natural experiment which may overcome this problem.

I study the effect of the pre-deregulation level of leverage on the subsequent survival of trucking firms during deregulation. I find that firms that happened to be highly leveraged at the beginning of deregulation are less likely to survive afterward, even when controlling for some measures of efficiency and for the ex-ante probability of default.

I find that the initial level of leverage has a negative impact on the ability of a motor carrier to invest in the years following deregulation. The effect is particularly pronounced in the companies that are eventually forced to exit, suggesting that the underinvestment problem caused by the high debt level might have forced these firms out of the market.

I also find evidence that the pre-deregulation level of leverage negatively impacts the price that a carrier charged during the price war which followed deregulation. This effect is entirely 
concentrated in the LTL segment of the industry.

In general, my findings raise the possibility that sometimes natural selection leads to the survival of relatively inefficient firms, which happens (or choose) to have deep pockets. In industries with high barriers to entry (like LTL shipments) relatively inefficient firms that survive are not likely to be challenged by new entrants. Thus, in these industries, these selection "mistakes" may have long-lasting effects. In other words, my findings challenge the commonly-held assumption that competition will necessarily lead to the survival of the fittest. Only future research will be able to answer how generalizable these findings are. 


\section{Appendix: Technical measure of efficiency}

The first step consists of estimating a production function with a panel of firms. The firm specific effect represents the difference between a firm's output and the predicted level of output given the observed inputs. This difference can be used to assess the relative degree of inefficiency of each firm with respect to the most productive firm in the sample.

I use the period 1976-1978 to estimate the degree of relative inefficiency before deregulation started. ${ }^{17}$ Following the literature on the subject, and especially its application to the trucking industry (see Friedlaender and Spady (1981)), I estimated a translog production function of the form

$$
\ln Y_{i t}=\alpha_{i}+\sum_{z}^{K} \beta_{z} \ln X_{z i t}+\sum_{z}^{K} \gamma_{z} \frac{\ln ^{2} X_{z i t}}{2}+\sum_{z}^{K} \sum_{j}^{K} \delta_{z j} \ln X_{z i t} \ln X_{j i t}+\sum_{l}^{L} F_{l i t}+\epsilon_{i t}
$$

where $\ln Y_{i t}$ is the logarithm of firm $i$ 's output at time $t, X_{z}$ are the $K$ factors used in the production process, and $F_{l}$ are $L$ controlling factors to account for possible heterogeneity of the principal input categories.

In this context, the firm's specific factor $\alpha_{i}$ is the algebraic sum of a common intercept $\alpha$ and a firm specific level of inefficiency $u_{i}$ :

$$
\alpha_{i}=\alpha-u_{i}
$$

The output $\mathrm{Y}$ is the number of ton-miles transported by carrier $i$ in year $t$. The factors used are capital (net carrier operating properties), labor (number of workers) and intermediate goods (deflated expenses in fuel and supplies). As controlling factor I used the size of the average haul and the average load, plus two yearly dummies. The within estimates of equation (3) are presented in Table 17.

The estimates look reasonable. The estimated elasticity of output with respect to capital is 0.09 , with respect to labor 0.20 , and the elasticity with respect to fuel and supplies is 0.32 . The within regression can explain 60 percent of the variability.

Schmidt and Sickles's (1984) intuition is that the estimated firm-specific effect $\hat{\alpha}_{i}$ can be 
used to obtain an estimate of the production inefficiency of firm $i\left(\hat{u}_{i}\right)$. This is obtained as

$$
\hat{u}_{i}=\max \left\{\hat{\alpha}_{i}\right\}-\hat{\alpha}_{i}
$$

I estimate the $\hat{u}_{i}$ by using regression (3) and then use the estimated value as a measure of inefficiency in regression (2). 


\section{References}

Altman, Edward, 1968, Financial Ratios, Discriminant Analysis, and the Prediction of Corporate Bankruptcy, Journal of Finance 23, 589-609.

Altman, Edward, 1973, Predicting Railroad Bankruptcies in America, Bell Journal of Economics and Management 4, 184-211.

Bolton Patrick, and David Scharfstein, 1990, A Theory of Predation Based on Agency Problems in Financial Contracting, American Economic Review 80, 93-106.

Breen, Dennis A., 1977, The Monopoly Value of Household-Goods Carrier Operating Certificates, The Journal of Law and Economics 20, 153-185.

Brander James, and Tracy Lewis, 1986, Oligopoly and Financial Structure, American Economic Review 76, 956-970.

Chevalier, Judith, 1995a, Capital Structure and Product Market Competition: Empirical Evidence from the Supermarket Industry, American Economic Review 85, 206-256.

Chevalier, Judith, 1995b, Do LBO Supermarkets Charge More: An Empirical Analysis of the Effects of LBOs on Supermarket Pricing, Journal of Finance 50, 1095-1113.

Chevalier, Judith, and David Scharfstein, 1996, Capital-Market Imperfections and Countercyclical Markups: Theory and Evidence, American Economic Review 86, 703-725 .

Friedlaender, Ann, and Richard H. Spady, 1981. Freight Transport Regulation. Equity Efficiency, and Competition in the Rail and Trucking Industries, (The MIT Press, Cambridge, MA).

Glaskowsky, Nicholas A., 1986. Effects of Deregulation on Motor Carriers, (Eno Foundation for Transportation Inc, Westport, CT).

Harris, Milton and Artur Raviv, 1990, Capital Structure and the Informational Role of Debt, Journal of Finance 45, 321-350. 
Holtz-Eakin, Douglas, David Jouflaian, and Harvey Rosen, 1994, Sticking It Out: Entrepreneurial Survival and Liquidity Constraint, Journal of Political Economy 102, 53-75.

Kovenock, Dan, and Gordon M. Phillips, 1997, Capital Structure and Product Market Behavior: An Examination of Plant Exit and Investment Decisions, Review of Financial Studies forthcoming.

Jensen Michael C., 1986, Agency Costs of Free Cash Flow, Corporate Finance and Takeovers, American Economic Review 76, 323-329.

Jensen, Michael C., 1989, The Eclipse of the Public Corporation, Harvard Business Review $67,61-74$.

Lang, Larry, Eli Ofek, and Renè Stulz, 1996, The Leverage, Investment, and Firm Growth, Journal of Financial Economics 40, 3-31.

Maksimovic, Vojislav, and Sheridan Titman, 1991, Financial Policy and Reputation for Product Quality, Review of Financial Studies 4, 175-200.

Moore, Thomas G., 1978, The Beneficiaries of Trucking Regulation, The Journal of Law and Economics 21, 327-344.

Moore, Thomas G., 1986, Rail and Trucking Deregulation in Leonard W. Weiss and Michael W. Klass eds.: Regulatory Reform. What Actually Happened, (Little Brown and Company, Boston, MA).

Myers, Stewart C., 1977, The Determinants of Corporate Borrowing, Journal of Financial Economics 5, 146-175.

Myers, Stewart C., 1984, The Capital Structure Puzzle, Journal of Finance 89, 575-592.

Perotti, Enrico, and Kathryn Spier, 1993, Capital Structure as a Bargaining Tool: The Role of Leverage in Contract Renegotiation, American Economic Review 83, 1131-1141.

Phillips, Gordon., 1995, Increased Debt and Product-Market Competition, Journal of Financial Economics 37, 189-238. 
Rajan, Raghuram, and Luigi Zingales, 1995, What Do We Know About Capital Structure? Some Evidence From International Data, Journal of Finance 50, 1421-1460.

Rose, Nancy, 1985, The Incidence of Regulatory Rents in the Motor Carrier Industry, Rand Journal of Economics 16, 299-318.

Rose, Nancy, 1987, Labor Rent Sharing and Regulation: Evidence from the Trucking Industry, Journal of Political Economy 95, 1146-1178.

Schipper, Katherine, Rex Thompson, and Roman L. Weil, 1987, Disentangling Interrelated Effects of Regulatory Changes on Shareholder Wealth: The Case of Motor Carrier Deregulation, Journal of Law and Economics 30, 67-100.

Schmidt, Peter, and Robin C. Sickles, 1984, Production Frontiers and Panel Data, Journal of Business and Economic Statistics 2, 367-374.

Smith Clifford W. Jr., and Ross L. Watts, 1992, The Investment Opportunity Set and Corporate Financing, Dividend, and Compensation Policies, Journal of Financial Economics 32, 263-292.

Spence, Michael, 1985, Capital Structure and the Corporation's Product Market Environment in Benjamin M. Friedman ed.: Corporate Capital Structures in the United States (The University of Chicago Press, Chicago, IL).

Standard \& Poors, various years, S\&P Industry Outlook .

Stulz, René, 1990, Managerial Discretion and Optimal Financing Policies, Journal of Financial Economics 26, 3-28.

Telser, Lester G., 1966, Cutthroat Competition and the Long Purse, Journal of Law and Economics 9, 259-277.

Titman, Sheridan, 1984, The Effect of Capital Structure on a Firm's Liquidation Decision, Journal of Financial Economics, 13, 137 - 151. 
Winston, Clifford, 1993, Economic Deregulation: Days of Reckoning for Microeconomists, Journal of Economic Literature 31, 1263-1289. 


\section{Notes}

1 United Press International, January 19, 1986.

2 Ibid.

3 The New York Times, December 13, 1983.

4 As Glaskowsky (1986) points out, while the TL segment of the industry is fairly close to the textbook definition of a competitive market, with no significant economies of scale, very low barriers to entry and many atomistic players, "the LTL carrier segment is not atomistic in any sense of the word. A small and still shrinking group of increasingly large firms dominates this traffic nationally. LTL operations do have significant economies of scale. The established large national LTL carriers are beneficiaries of an almost insurmountable financial barrier to entry: their large and widespread terminal networks." The emphasis is in the original text.

5 One could claim that regulatory actions are not independent of the economic performance. Although this argument is generally valid, it does not seem to fit well the trucking deregulation. For instance, Rothenberg (1987), as cited in Rose (1987) argues that motor carrier deregulation was largely independent of interest lobbying activity. In fact, both the American Trucking Association and the Teamsters Union aggressively opposed deregulation.

${ }^{6}$ Assume that, after partialing out the observable measures of qualities, the true relationship between survival and leverage is given by $y=x \beta+z \gamma+\epsilon$, where $x$ is leverage and $z$ is an unobservable measure of quality. The concern is that $\operatorname{cov}(z, x) \neq 0$ so that $\hat{\beta}$ is inconsistent. In particular, I am concerned that $\operatorname{cov}(z, x)<0$, i.e., worse quality firms are more highly leveraged. This is the case in a pecking order theory à la Myers (1984), where firms become highly leveraged because they are unprofitable. In this case, however, $\operatorname{cov}(z, x)$ will be the same across different market segments. I can, then, divide the sample in high LTL carriers and high TL carriers. In a linear probability model the estimate of the impact of leverage on survival in the two groups is given by

$$
\hat{\beta}_{L T L}=\beta_{L T L}+\frac{\operatorname{cov}(z, x)}{\operatorname{var}(x)} \gamma_{L T L}+\frac{\operatorname{cov}(z, x)}{\operatorname{var}(x)} \epsilon_{L T L}
$$

and

$$
\hat{\beta}_{T L}=\beta_{T L}+\frac{\operatorname{cov}(z, x)}{\operatorname{var}(x)} \gamma_{T L}+\frac{\operatorname{cov}(z, x)}{\operatorname{var}(x)} \epsilon_{T L} .
$$

If the impact of quality on survival is similar between the two groups (i.e., $\gamma_{T L}=\gamma_{L T L}$ ), then the difference between the two estimated coefficients is a consistent estimate of the true difference between the two coefficients. 
7 Cited in Glaskowsky (1986).

8 The results are not sensitive to the level of this cutoff. In fact, the pre 1980 exits appear to be uncorrelated with leverage.

${ }^{9}$ Whenever EBITDA is negative I put the value of coverage to zero. If coverage exceeds 100 or the interest expenses are zero I artificially equate coverage to 100 .

${ }_{10}$ One might wonder whether these differences in leverage simply reflect differences in the investment opportunities across firms (see for example Smith and Watts (1992)). However, Rajan and Zingales (1995) show that the negative relation between investment opportunities (measured as Tobin's q) and leverage appears to be mainly driven by equity issuers. Since almost all the firms in this sample are privately held (and thus cannot issue equity at wish), this negative correlation is not likely to be a major source of concern.

11 This argument, although standard, is necessarily appropriate to this case because the industry was regulated until 1977, and thus the size of a firm may be influenced more by regulation than by efficiency.

12 These intangibles might also appear in the balance sheet in case of a merger, if the acquiring company used the purchased method of accounting. In such case, the potential impact of intangibles is ambiguous.

13 In their original article Schmidt and Sickels (1984) apply their technique to the airline industry and find that there is no link between estimated inefficiency and survival of airline carriers.

${ }_{14}$ It also implies that the 1977 level of leverage has some predictive power on the probability of a firm's survival between three and eight years after. This rejects the hypothesis that the impact of leverage on survival is simply driven by firms on the verge of bankruptcy in 1977 .

15 A preferable alternative would be to estimate the Z-score model with trucking data. Unfortunately, the ATA dataset starts in 1976, making it impossible to estimate the Z-score model for trucking firms in the pre-deregulation period

16 Altman (1973) uses a three year growth rate, but I use the one year growth because I have just one year of accounting data for the pre-1977 period.

17 The estimator of a firm's inefficiency is consistent for $\mathrm{T}$ (number of periods) going to infinity. Therefore. I decide to include 1978 as a pre-deregulation year to increase the precision of the estimates. I also try to estimate a model using data up to 1980 without significant changes in the results. 
Table I

\section{Industry Segments in $\mathbf{1 9 7 7}$}

This table reports the distribution by main activity (types of goods hauled) of the 3,150 carriers reporting to the Interstate Commerce Commission (ICC) in 1977. These categories can be thought of as different market segments. The data used comes from the American Trucking Association, which has been collecting and reclassifying Interstate Commerce Commission filings since 1976. In the rest of the paper, I focus only on general freight carriers.

\begin{tabular}{lrr} 
Commodity & Freq. & Percent \\
\hline General Freight & 1300 & 41.27 \\
Household Goods & 248 & 7.87 \\
Heavy Machinery & 80 & 2.54 \\
Petroleum Products & 162 & 5.14 \\
Refrigerated Liquids & 12 & 0.38 \\
Refrigerated Solids & 143 & 4.54 \\
Dump Trucking & 84 & 2.67 \\
Agricultural Commodity & 97 & 3.08 \\
Motor Vehicles & 49 & 1.56 \\
Armored Truck Service & 2 & 0.06 \\
Building Materials & 135 & 4.29 \\
Films \& Associated Commodities & 5 & 0.16 \\
Forest Products & 22 & 0.70 \\
Mine Ores not including Coal & 5 & 0.16 \\
Retail Store Delivery Service & 26 & 0.83 \\
Dangerous and Hazardous Materials & 7 & 0.22 \\
Other Commodities not elsewhere classified & 773 & 24.54 \\
\hline Total & 3,150 & 100.00 \\
\hline \hline
\end{tabular}


Table II

\section{Summary Statistics}

Population of 941 general freight carriers with more than one million in operating revenues in 1977. Variables are defined in panel $A$ and are averages of the 1976 and 1977 values. Advance payables include any notes payable. Negative book values of equity are set equal to zero. Coverage is set equal to zero when earnings before interest, taxes, and depreciation (EBITDA) is less than or equal to zero and equal to 100 when coverage is greater or equal to 100 . Observations with a return on assets larger than 1 or smaller than -1 are set equal to missing. The difference column reports the difference in means between carriers that were still alive in 1985 and carriers that were not alive at that date. The p-values refer to the null hypothesis that the difference between the two means is equal to zero.

\section{Panel A: Variable Definitions}

\begin{tabular}{ll}
\hline Variable & Definition \\
Average Load & Ton-miles/Total miles \\
Average Haul & Ton-miles hauled/Tons of revenue freight \\
Cost per ton-mile & Operating expenses / Ton-miles hauled \\
Coverage & EBITDA/ Interest expenses \\
Debt & Short term + Long term debt + Advances payables \\
Debt-to-capital & Debt/ Debt + Equity \\
Intangibles & Intangibles/ Total assets \\
Labor cost & (Wages + Benefits)/ Operating costs \\
Net debt-to-capital & (Debt - Cash reserves) / Debt + Equity \\
Market share & Operating revenues/Total operating revenues of carriers in the same state \\
Proportion LTL revenues & Freight revenues up to 10,000 pounds/ Freight revenues \\
Return on assets & EBITDA/ Total assets \\
Return on sales & EBITDA/ Operating revenues \\
Revenue per ton-mile & Operating revenues/ Ton-miles hauled \\
\hline
\end{tabular}


Panel B: Summary Statistics

\begin{tabular}{lcccccccc}
\hline & & & & & & & & \\
Variable & 15.0 & 3.1 & 4.75 & 0.90 & 684 & 6.33 & 0.041 & 941 \\
\hline Revenues (Mill.) & 6.88 & 1.2 & 2.41 & 0.05 & 355 & 4.08 & 0.009 & 941 \\
Assets (Mill.) & 0.40 & 0.35 & 0.30 & 0.00 & 1.00 & -0.10 & 0.000 & 940 \\
Debt-to-capital & 0.22 & 0.20 & 0.38 & -0.97 & 1.00 & -0.13 & 0.000 & 910 \\
Net debt-to-capital & 27.33 & 9.78 & 33.42 & 0.00 & 100 & 11.0 & 0.000 & 923 \\
Coverage & 0.18 & 0.18 & 0.13 & -0.45 & 0.88 & 0.07 & 0.000 & 939 \\
Return on assets & 0.08 & 0.07 & 0.06 & -0.43 & 0.52 & 0.04 & 0.000 & 941 \\
Return on sales & 0.06 & 0.03 & 0.08 & 0.00 & 0.64 & -0.01 & 0.005 & 930 \\
Intangibles & 0.48 & 0.54 & 0.18 & 0.01 & 0.88 & -0.03 & 0.005 & 939 \\
Labor cost & 0.32 & 0.21 & 0.42 & 0.02 & 6.9 & -0.03 & 0.405 & 773 \\
Revenue per ton-mile & 0.41 & 0.21 & 0.70 & 0.00 & 6.9 & -0.09 & 0.059 & 768 \\
Cost per ton-mile & 0.58 & 0.66 & 0.27 & 0.00 & 1.00 & 0.00 & 0.949 & 649 \\
Proportion LTL revenues & 10.2 & 10.0 & 5.3 & 0.47 & 36.5 & 0.26 & 0.502 & 772 \\
Average load & 227.1 & 169.4 & 210.0 & 6.9 & 1713 & -27.7 & 0.105 & 606 \\
Average haul & 0.05 & 0.01 & 0.12 & 0.00 & 1.00 & 0.02 & 0.016 & 941 \\
Market share & 418 & 86 & 1405 & 2 & 26,035 & 185 & 0.048 & 906 \\
Number of employees & & & & & & & & \\
\hline
\end{tabular}




\section{Table IV}

\section{Robustness to Different Measures of Efficiency}

The dependent variable is the probability that a general freight motor carrier with more than one million in revenues in 1977 survives until 1985. The reported coefficients are probit estimates of the effect of a marginal change in the corresponding regressor on the probability of survival, computed at the average of the dependent variable. Net debt-to-capital is total debt minus cash reserves divided by total debt plus equity. Intangibles is the ratio of intangible assets to total assets. Labor cost is the ratio of the wages and benefits to operating costs. All the independent variables are measured as of 1977 (average of the 1976 and 1977 values) except that the 1980 return on sales in the last column. Column I uses the estimated inefficiency of a carrier as additional proxy for a carrier's efficiency. This is computed as the distance of its output from the production frontier, estimated using a translog function (see Appendix). Column II uses as additional proxy for efficiency the cost per ton-mile. Cost per ton-mile is the ratio of operating expenses to ton-miles hauled. Column III uses the ex-post value of efficiency as of 1980 as a proxy for efficiency. In such case the dependent variable is the probability of survival after 1980. All regressions contain nine regional dummies (not reported). Standard errors are reported in parentheses.

\begin{tabular}{lccc}
\hline Independent & & & \\
Variables & $\mathrm{I}$ & $\mathrm{II}$ & $\mathrm{III}$ \\
\hline Net debt-to-capital & $-0.246^{* * *}$ & $-0.225^{* * *}$ & $-0.277^{* * *}$ \\
& $(0.066)$ & $(0.057)$ & $(0.058)$ \\
Return on sales & $3.157^{* * *}$ & $3.102^{* * *}$ & $1.131^{* *}$ \\
& $(0.481)$ & $(0.407)$ & $(0.512)$ \\
$\log$ (Revenues) & $0.031^{*}$ & $0.029^{*}$ & 0.022 \\
& $(0.017)$ & $(0.016)$ & $(0.015)$ \\
Intangibles & -0.038 & -0.228 & -0.066 \\
& $(0.302)$ & $(0.272)$ & $(0.280)$ \\
Labor cost & $-0.335^{* *}$ & $-0.436^{* * *}$ & -0.187 \\
& $(0.152)$ & $(0.123)$ & $(0.119)$ \\
Estimated inefficiency & $0.506^{*}$ & & \\
& $(0.266)$ & & \\
Cost per ton-mile & & -0.019 & \\
Return on sales in 1980 & & $(0.032)$ & \\
& & & $2.450^{* * *}$ \\
Pseudo- $R^{2}$ & & & $(0.452)$ \\
$\mathrm{N}$ & & & \\
\hline
\end{tabular}

*** indicates the coefficient is significantly different from zero at the $1 \%$ level or less;

** indicates the coefficient is significantly different from zero at the $5 \%$ level;

* indicates that the coefficient is significantly different from zero at the $10 \%$ level. 
Table III

\section{Effect of Initial Leverage on the Probability of Survival}

The dependent variable is the probability that a general freight motor carrier with more than one million in revenues in 1977 survives until 1985. The reported coefficients are probit estimates of the effect of a marginal change in the corresponding regressor on the probability of survival, computed at the average of the dependent variable. All the independent variables are measured as of 1977 (average of the 1976 and 1977 values). Net debt-to-capital is total debt minus cash reserves divided by total debt plus equity. Intangibles is the ratio of intangible assets to total assets. Labor cost is the ratio of the wages and benefits to operating costs. Among the independent variables there are also nine regional dummies (not reported). Standard errors are reported in parentheses.

\begin{tabular}{lccc}
\hline $\begin{array}{l}\text { Independent } \\
\text { Variables }\end{array}$ & $\mathrm{I}$ & $\mathrm{II}$ & $\mathrm{III}$ \\
\hline Net debt-to-capital & $-0.179^{* * *}$ & $-0.184^{* * *}$ & \\
& $(0.048)$ & $(0.048)$ & \\
$\log (1+$ Coverage $)$ & & & $0.042^{* * *}$ \\
& & & $(0.015)$ \\
Return on sales & $2.870^{* * *}$ & & $2.567^{* * *}$ \\
& $(0.343)$ & & $(0.356)$ \\
Return on assets & & $0.793^{* * *}$ & \\
& & $(0.134)$ & \\
log(Revenues) & $0.048^{* * *}$ & $0.044^{* * *}$ & $0.043^{* * *}$ \\
& $(0.014)$ & $(0.014)$ & $(0.014)$ \\
Intangibles & -0.292 & $-0.583^{* *}$ & -0.346 \\
& $(0.247)$ & $(0.245)$ & $(0.242)$ \\
Labor cost & $-0.324^{* * *}$ & $-0.233^{* *}$ & $-0.317^{* * *}$ \\
& $(0.102)$ & $(0.103)$ & $(0.100)$ \\
Pseudo- $R^{2}$ & & & \\
$\mathrm{~N}$ & 0.12 & 0.09 & 0.12 \\
\hline
\end{tabular}

*** indicates the coefficient is significantly different from zero at the $1 \%$ level or less;

** indicates the coefficient is significantly different from zero at the $5 \%$ level;

* indicates that the coefficient is significantly different from zero at the $10 \%$ level. 


\section{Table V \\ Effect of Leverage Controlling for the Ex Ante Risk of Default}

The dependent variable is the probability that a general freight motor carrier with more than one million in revenues in 1977 survives until 1985. The reported coefficients are probit estimates of the effect of a marginal change in the corresponding regressor on the probability of survival, computed at the average of the dependent variable. Net debt-to-capital is total debt minus cash reserves divided by total debt plus equity. Intangibles is the ratio of intangible assets to total assets. Labor cost is the ratio of the wages and benefits to operating costs. The first column reports the results of the basic regression of the probability of survival when the Altman Z-score is used as an additional explanatory variable. Altman Z-score is an index, based on accounting information, of the risk of default. The higher the Z-score, the lower the probability of default is. The second regression reports results of the basic regression of the probability of survival conditioned on the fact the Z-score model predicted survival. The third regression reports the results of the basic regression of the probability of survival conditioned on the fact the Z-score model predicted default. All regressions contain nine regional dummies (not reported). Standard errors are reported in parentheses.

\begin{tabular}{lccc}
\hline $\begin{array}{l}\text { Independent } \\
\text { Variables }\end{array}$ & & $\begin{array}{c}\text { Predicted } \\
\text { Survivors }\end{array}$ & $\begin{array}{c}\text { Predicted } \\
\text { Defaults }\end{array}$ \\
\hline Net debt-to-capital & $-0.150^{* *}$ & $-0.204^{* *}$ & $-0.183^{* *}$ \\
& $(0.064)$ & $(0.080)$ & $(0.083)$ \\
Return on sales & $2.344^{* * *}$ & $3.004^{* * *}$ & $2.150^{* * *}$ \\
& $(0.393)$ & $(0.587)$ & $(0.525)$ \\
Log-Revenues & $0.039^{* * *}$ & $0.080^{* * *}$ & 0.017 \\
& $(0.015)$ & $(0.024)$ & $(0.019)$ \\
Intangibles & -0.364 & $-0.655^{*}$ & 0.113 \\
& $(0.260)$ & $(0.358)$ & $(0.371)$ \\
Labor cost & -0.151 & $-0.340^{* *}$ & -0.306 \\
& $(0.149)$ & $(0.167)$ & $(0.319)$ \\
Z-Score & $0.011^{* *}$ & & \\
& $(0.005)$ & & \\
Pseudo- $R^{2}$ & & & \\
$\mathrm{~N}$ & 0.13 & 0.15 & 0.07 \\
\hline
\end{tabular}

*** indicates the coefficient is significantly different from zero at the $1 \%$ level or less;

** indicates the coefficient is significantly different from zero at the $5 \%$ level;

* indicates that the coefficient is significantly different from zero at the $10 \%$ level. 
Table VI

\section{Summary Statistics Split According to the Industry Segment}

General freight carriers with more than one million in operating revenues in 1977 are divided in three groups according to the fraction of their revenues coming from less-thantruckload shipments as of 1977. Net debt-to-capital is total debt minus cash reserves divided by total debt plus equity. Intangibles is the ratio of intangible assets to total assets. Labor cost is the ratio of the wages and benefits to operating costs. Revenues per ton-mile is is the ratio of operating revenues to ton-miles hauled. Average load is the ratio of ton-miles hauled to total miles traveled. Average haul is the ratio of ton-miles hauled to tons of revenues freight. Market share is the ratio between a carriers' operating revenues and the sum of the operating revenues of all the carriers located in the same state. The difference column reports the difference in means between carriers that still existed in 1985 and carriers that did not exist at that date. The p-values refer to the null that the difference is equal to zero.

Panel A: Carriers with less that 30 percent of revenues from LTL

\begin{tabular}{lcccccccc}
\hline Variable & Mean & Median & St. Dev. & Min. & Max. & Diff. & p-value & Obs \\
\hline Revenues (Mill.) & 5.35 & 2.45 & 7.85 & 0.92 & 46.60 & 3.61 & 0.014 & 113 \\
Assets (Mill.) & 2.06 & 0.90 & 3.32 & 0.16 & 23.70 & 1.86 & 0.003 & 113 \\
Debt-to-capital & 0.45 & 0.38 & 0.32 & 0.00 & 1.00 & -0.03 & 0.575 & 113 \\
Net debt-to-capital & 0.27 & 0.25 & 0.43 & -0.88 & 0.99 & 0.00 & 0.984 & 109 \\
Coverage & 22.27 & 7.52 & 30.10 & 0.00 & 100.00 & 3.52 & 0.538 & 112 \\
Return on assets & 0.19 & 0.19 & 0.13 & -0.19 & 0.73 & 0.05 & 0.033 & 113 \\
Return on sales & 0.08 & 0.07 & 0.07 & -0.03 & 0.42 & 0.02 & 0.059 & 113 \\
Intangibles & 0.07 & 0.03 & 0.08 & 0.00 & 0.44 & -0.01 & 0.740 & 111 \\
Labor cost & 0.28 & 0.30 & 0.18 & 0.02 & 0.64 & -0.04 & 0.198 & 112 \\
Revenues per ton-mile & 0.11 & 0.07 & 0.10 & 0.03 & 0.62 & -0.01 & 0.625 & 90 \\
Cost per ton-mile & 0.19 & 0.07 & 0.41 & 0.03 & 3.68 & -0.12 & 0.170 & 90 \\
Average load & 13.55 & 13.45 & 5.75 & 1.00 & 31.10 & 0.96 & 0.432 & 90 \\
Average haul & 252.51 & 217.64 & 196.32 & 6.93 & 1164.46 & 74.62 & 0.077 & 87 \\
Market share & 0.05 & 0.01 & 0.13 & 0.00 & 1.00 & 0.03 & 0.156 & 113 \\
Number of employees & 88.89 & 47.25 & 114.28 & 2.00 & 596.50 & 23.60 & 0.290 & 106 \\
\hline
\end{tabular}


B: Carriers with between 30 percent and 70 percent of revenues from LTL

\begin{tabular}{lcccccccc}
\hline Variable & Mean & Median & St. Dev. & Min. & Max. & Diff. & p-value & Obs \\
\hline Revenues (Mill.) & 28.80 & 6.79 & 56.60 & 0.95 & 508.00 & 4.42 & 0.530 & 266 \\
Assets (Mill.) & 13.80 & 2.48 & 32.00 & 0.05 & 309.00 & 5.06 & 0.203 & 266 \\
Debt-to-capital & 0.42 & 0.36 & 0.29 & 0.00 & 1.00 & -0.13 & 0.000 & 265 \\
Net debt-to-capital & 0.25 & 0.26 & 0.36 & -0.86 & 1.00 & -0.20 & 0.000 & 257 \\
Coverage & 24.55 & 8.67 & 31.66 & 0.00 & 100.00 & 12.72 & 0.001 & 261 \\
Return on assets & 0.17 & 0.17 & 0.14 & -0.30 & 0.88 & 0.08 & 0.000 & 264 \\
Return on sales & 0.07 & 0.07 & 0.07 & -0.43 & 0.52 & 0.05 & 0.000 & 266 \\
Intangibles & 0.07 & 0.04 & 0.09 & 0.00 & 0.64 & -0.01 & 0.293 & 265 \\
Labor cost & 0.52 & 0.55 & 0.13 & 0.01 & 0.76 & -0.00 & 0.942 & 266 \\
Revenues per ton-mile & 0.24 & 0.18 & 0.21 & 0.06 & 1.86 & 0.03 & 0.230 & 259 \\
Cost per ton-mile & 0.26 & 0.18 & 0.32 & 0.06 & 2.46 & 0.04 & 0.286 & 259 \\
Average load & 10.90 & 11.45 & 4.21 & 0.80 & 29.54 & 0.35 & 0.504 & 259 \\
Average haul & 278.45 & 207.31 & 261.05 & 12.52 & 1713 & -61.39 & 0.062 & 258 \\
Market share & 0.08 & 0.02 & 0.14 & 0.00 & 0.94 & 0.02 & 0.273 & 261 \\
Number of employees & 760.90 & 199.25 & 1421.08 & 2.00 & 13157 & 148.26 & 0.401 & 266 \\
\hline
\end{tabular}

\section{C: Carriers with more than $\mathbf{7 0}$ percent of revenues from LTL}

\begin{tabular}{lcccccccc}
\hline Variable & Mean & Median & St. Dev. & Min. & Max. & Diff. & p-value & Obs \\
\hline Revenues (Mill.) & 14.70 & 3.70 & 55.70 & 0.93 & 684.00 & 11.70 & 0.083 & 270 \\
Assets (Mill.) & 6.73 & 1.45 & 28.50 & 0.23 & 355.00 & 6.83 & 0.048 & 270 \\
Debt-to-capital & 0.34 & 0.29 & 0.28 & 0.00 & 1.00 & -0.15 & 0.000 & 270 \\
Net debt-to-capital & 0.14 & 0.09 & 0.37 & -0.97 & 1.00 & -0.20 & 0.000 & 261 \\
Coverage & 33.10 & 13.35 & 36.05 & 0.00 & 100.00 & 19.66 & 0.000 & 264 \\
Return on assets & 0.19 & 0.18 & 0.12 & -0.33 & 0.56 & 0.06 & 0.000 & 270 \\
Return on sales & 0.08 & 0.07 & 0.05 & -0.07 & 0.30 & 0.04 & 0.000 & 270 \\
Intangibles & 0.06 & 0.04 & 0.07 & 0.00 & 0.47 & -0.02 & 0.007 & 268 \\
Labor cost & 0.56 & 0.59 & 0.11 & 0.02 & 0.78 & 0.00 & 0.923 & 269 \\
Revenues per ton-mile & 0.44 & 0.32 & 0.37 & 0.12 & 3.46 & 0.04 & 0.402 & 261 \\
Cost per ton-mile & 0.44 & 0.31 & 0.39 & 0.11 & 3.20 & 0.01 & 0.861 & 261 \\
Average load & 8.25 & 8.47 & 3.99 & 0.81 & 24.06 & -0.35 & 0.477 & 261 \\
Average haul & 167.98 & 134.76 & 126.86 & 17.45 & 788.00 & -11.60 & 0.461 & 261 \\
Market share & 0.05 & 0.01 & 0.12 & 0.00 & 0.90 & 0.02 & 0.204 & 270 \\
Number of employees & 426.64 & 114.25 & 1398.94 & 6.00 & 18015 & 310.07 & 0.072 & 264 \\
\hline
\end{tabular}




\section{Table VII \\ Differential Impact of the Initial Leverage on Survival in Different Segments of the Trucking Industry}

The dependent variable is the probability that a general freight motor carrier with more than one million in revenues in 1977 survives until 1985. The reported coefficients are probit estimates of the effect of a marginal change in the corresponding regressor on the probability of survival, computed at the average of the dependent variable. Net debt-to-capital is total debt minus cash reserves divided by total debt plus equity. Intangibles is the ratio of intangible assets to total assets. Labor cost is the ratio of the wages and benefits to operating costs. All the independent variables are measured as of 1977 (average of the 1976 and 1977 values). Among the independent variables there are also nine regional dummies (not reported). General freight carriers are divided into three groups according to the fraction of their revenues coming from less-than-truckload shipments as of 1977. The first column reports the estimates for motor carriers with less than 30 percent of revenues from less than truckload shipments (LTL). The estimates in the second column regards motor carriers with more than 30 percent but less than 70 percent of their revenues in LTL shipments. The estimates in the third column regards motor carriers with more than 70 percent of their revenues in LTL shipments. Standard errors are reported in parentheses.

\begin{tabular}{lccc}
\hline Independent & & & \\
Variables & LTL $<0.3$ & $0.3<$ LTL $<0.7$ & LTL $>0.7$ \\
\hline Net debt-to-capital & 0.021 & $-0.209^{* *}$ & $-0.277^{* * *}$ \\
& $(0.127)$ & $(0.102)$ & $(0.101)$ \\
Return on sales & $1.481^{*}$ & $3.255^{* * *}$ & $3.247^{* * *}$ \\
& $(0.829)$ & $(0.705)$ & $(0.821)$ \\
$\log$ (Revenues) & $0.125^{*}$ & -0.008 & $0.063^{* *}$ \\
& $(0.064)$ & $(0.023)$ & $(0.031)$ \\
Intangibles & 0.151 & 0.105 & -0.591 \\
& $(0.687)$ & $(0.424)$ & $(0.512)$ \\
Labor cost & -0.417 & 0.067 & -0.320 \\
& $(0.341)$ & $(0.276)$ & $(0.341)$ \\
Pseudo- $R^{2}$ & & & \\
$\mathrm{~N}$ & 0.09 & 0.17 & 0.15 \\
\hline
\end{tabular}

*** indicates the coefficient is significantly different from zero at the $1 \%$ level or less;

** indicates the coefficient is significantly different from zero at the $5 \%$ level;

* indicates that the coefficient is significantly different from zero at the $10 \%$ level. 


\section{Table VIII \\ Investments}

This table reports the OLS estimates obtained by regressing capital investments of general freight motor carriers with more than one million in revenues in 1977 on some pre-determined explanatory variables. Investments are computed as differences in carriers' gross operating properties over the period divided by the 1977 level of net operating properties. Net debt-tocapital is total debt minus cash reserves divided by total debt plus equity. Intangibles is the ratio of intangible assets to total assets. Labor cost is the ratio of the wages and benefits to operating costs. All the independent variables are measured as of 1977 (average of the 1976 and 1977 values). Column I considers the investment over the period 1977-1985, column II over the period 1977-1980. Column III considers the investment over the period 1977-1980, but restricts the sample to the motor carriers that survived until 1985, while column IV restricts it to motor carriers that exited between 1980 and 1985 . All the regressions also contain nine regional dummies (not reported). Standard errors are reported in parentheses.

\begin{tabular}{lcccc}
\hline $\begin{array}{l}\text { Independent } \\
\text { Variables }\end{array}$ & $\begin{array}{c}\text { Investment } \\
1977-1985\end{array}$ & $\begin{array}{c}\text { Investment } \\
1977-1980\end{array}$ & $\begin{array}{c}\text { Investment } \\
1977-1980 \\
\text { of survivors }\end{array}$ & $\begin{array}{c}\text { Investment } \\
1977-1980 \\
\text { of non survivors }\end{array}$ \\
\hline Net debt-to-capital & -0.092 & $-0.224^{* *}$ & -0.068 & $-0.379^{* *}$ \\
Return on sales & $(0.203)$ & $(0.106)$ & $(0.131)$ & $(0.180)$ \\
& $2.249^{*}$ & $2.208^{* * *}$ & $1.840^{* * *}$ & 1.619 \\
$\log ($ Revenues) & $(1.173)$ & $(0.693)$ & $(0.796)$ & $(1.493)$ \\
& $-0.125^{* *}$ & $-0.063^{* * *}$ & $-0.057^{* * *}$ & -0.034 \\
Intangibles & $(0.052)$ & $(0.028)$ & $(0.033)$ & $(0.053)$ \\
& -0.697 & 0.645 & 0.504 & 0.556 \\
Labor cost & $(1.137)$ & $(0.518)$ & $(0.733)$ & $(0.761)$ \\
& $-1.081^{* * *}$ & -0.087 & -0.005 & $-1.438^{* * *}$ \\
$R^{2}$ & $(0.393)$ & $(0.084)$ & $(0.082)$ & $(0.400)$ \\
$N$ & & & & 0.11 \\
\hline
\end{tabular}

*** indicates the coefficient is significantly different from zero at the $1 \%$ level or less;

** indicates the coefficient is significantly different from zero at the $5 \%$ level;

* indicates that the coefficient is significantly different from zero at the $10 \%$ level. 


\section{Table IX}

\section{Firm-Level Prices and Leverage}

This table reports OLS coefficient estimates for a sample of general freight motor carriers with more than one million in revenues in 1977 that disclose data on the volume of their shipments (Instruction 27 carriers). The dependent variable is the difference between the price per ton-mile charged by a carrier in the year of reference and the price charged in 1977. Net debt-to-capital in 1977 is debt minus cash reserves divided by debt plus equity. Labor cost in 1977 equals wages plus benefits over operating costs. A carrier market share in 1977 is the ratio between a carriers' operating revenues and the sum of the operating revenues of all the carriers located in the same state. Medium less-than-truckload (LTL) carriers are carriers with more than 30 percent but less than 70 percent of their revenues in LTL shipments. High LTL carriers are carriers with more than 70 percent of their revenues in LTL shipments. All the regressions contain state fixed effects (not reported). Standard errors are reported in parentheses.

\begin{tabular}{lcccccc}
\hline Independent & & & & & & \\
Variables & 1980 & 1981 & 1982 & 1983 & 1984 & 1985 \\
\hline Net debt-to-capital & 0.046 & -0.037 & $-0.138^{* * *}$ & $-0.126^{* *}$ & $-0.120^{* *}$ & -0.103 \\
in 1977 & $(0.031)$ & $(0.040)$ & $(0.051)$ & $(0.050)$ & $(0.058)$ & $(0.073)$ \\
Labor cost & 0.092 & 0.088 & 0.087 & 0.249 & $0.328^{*}$ & 0.201 \\
in 1977 & $(0.090)$ & $(0.124)$ & $(0.159)$ & $(0.157)$ & $(0.193)$ & $(0.240)$ \\
Market share & 0.059 & 0.114 & 0.058 & 0.134 & 0.096 & 0.108 \\
in 1977 & $(0.098)$ & $(0.120)$ & $(0.154)$ & $(0.160)$ & $(0.180)$ & $(0.211)$ \\
Medium LTL revenues & 0.054 & $0.089^{*}$ & 0.063 & -0.008 & -0.015 & -0.023 \\
in 1977 & $(0.039)$ & $(0.052)$ & $(0.064)$ & $(0.065)$ & $(0.080)$ & $(0.101)$ \\
High LTL revenues & $0.107^{* *}$ & $0.141^{* *}$ & $0.119^{*}$ & 0.080 & 0.034 & 0.066 \\
in 1977 & $(0.042)$ & $(0.055)$ & $(0.068)$ & $(0.069)$ & $(0.082)$ & $(0.106)$ \\
& & & & & & \\
$R^{2}$ & 0.14 & 0.17 & 0.16 & 0.20 & 0.22 & 0.22 \\
$\mathrm{~N}$ & 429 & 376 & 354 & 333 & 302 & 264 \\
\hline
\end{tabular}

*** indicates the coefficient is significantly different from zero at the $1 \%$ level or less;

** indicates the coefficient is significantly different from zero at the $5 \%$ level;

* indicates that the coefficient is significantly different from zero at the $10 \%$ level. 
Table X

\section{Prices and Leverage in Different Segments of the Trucking Industry}

This table reports OLS coefficient estimates for a sample of general freight motor carriers with more than one million in revenues in 1977 that disclose data on the volume of their shipments (Instruction 27 carriers). The dependent variable is the vector of the differences between the price per ton-mile charged by a carrier in any year between 1980 and 1985 and the price charged in 1977. Net debt-to-capital in 1977 is debt minus cash reserves divided by debt plus equity. Labor cost in 1977 equals wages plus benefits over operating costs. A carrier market share in 1977 is the ratio between a carriers' operating revenues and the sum of the operating revenues of all the carriers located in the same state. The first column reports the estimates for motor carriers with less than 30 percent of revenues from less than truckload shipments (LTL). The estimates in the second column regard motor carriers with more than 30 percent but less than 70 percent of their revenues in LTL shipments. The estimates in the third column regard motor carriers with more than 70 percent of their revenues in LTL shipments. All the regressions contain state fixed effects and yearly dummies (not reported). Standard errors are reported in parentheses.

\begin{tabular}{lccc}
\hline Independent & & & \\
Variables & LTL $<0.3$ & $0.3<$ LTL $<0.7$ & LTL $>0.7$ \\
\hline Net debt-to-capital in 1977 & 0.087 & 0.027 & 0.017 \\
$\star 1980$ dummy & $(0.056)$ & $(0.054)$ & $(0.069)$ \\
Net debt-to-capital in 1977 & 0.108 & -0.053 & -0.080 \\
$\star 1981$ dummy & $(0.063)$ & $(0.056)$ & $(0.079)$ \\
Net debt-to-capital in 1977 & 0.080 & -0.090 & $-0.239^{* * *}$ \\
$\star 1982$ dummy & $(0.062)$ & $(0.058)$ & $(0.079)$ \\
Net debt-to-capital in 1977 & 0.037 & -0.064 & $-0.222^{* * *}$ \\
$\star 1983$ dummy & $(0.066)$ & $(0.061)$ & $(0.084)$ \\
Net debt-to-capital in 1977 & 0.002 & -0.054 & $-0.212^{* *}$ \\
$\star 1984$ dummy & $(0.076)$ & $(0.062)$ & $(0.083)$ \\
Net debt-to-capital in 1977 & 0.074 & $-0.130^{* *}$ & -0.091 \\
$\star 1985$ dummy & $(0.079)$ & $(0.066)$ & $(0.091)$ \\
Labor cost & 0.086 & $0.281^{* * *}$ & 0.185 \\
& $(0.083)$ & $(0.083)$ & $(0.144)$ \\
Market share & -0.078 & $0.189^{* *}$ & -0.112 \\
& $(0.514)$ & $(0.076)$ & $(0.134)$ \\
$R^{2}$ & & & \\
N & 0.19 & 0.24 & 0.12 \\
\hline
\end{tabular}

${ }_{* * *}$ indicates the coefficient is significantly different from zero at the $1 \%$ level or less;

** indicates the coefficient is significantly different from zero at the $5 \%$ level;

* indicates that the coefficient is significantly different from zero at the $10 \%$ level. 
Table XI

\section{Production Function Estimate}

This table reports a fixed effect estimate of a translog production function where capital $(\mathrm{K})$, labor $(\mathrm{L})$ and intermediate goods $(\mathrm{M})$ are the three factors. The sample is an unbalanced panel of firms present for at least two years in the period 1976-1978. The dependent variable is the logarithm of ton-miles hauled each year. Capital is the book value of net carrier operating properties. Labor is the number of workers employed. Intermediate goods are deflated expenses in fuel and supplies. As a factor controlling for possible heterogeneity of the principal input categories, the average haul and the average load, plus two yearly dummies are used. The average load is the ratio of ton-miles hauled to total miles traveled. The average haul is the ratio of ton-miles hauled to tons of revenues freight. Standard errors are reported in parentheses.

\begin{tabular}{lc}
\hline $\log \mathrm{K}$ & $-0.432^{* * *}$ \\
& $(0.078)$ \\
$\log \mathrm{L}$ & $0.832^{* * *}$ \\
& $(0.112)$ \\
$\log \mathrm{M}$ & $-0.334^{* *}$ \\
& $(0.147)$ \\
$\frac{(\log K)^{2}}{2}$ & $0.040^{* * *}$ \\
$\frac{(\log L)^{2}}{2}$ & $(0.007)$ \\
$\frac{(\log M)^{2}}{2}$ & $0.110^{* * *}$ \\
& $(0.016)$ \\
$\log \mathrm{K} \log \mathrm{L}$ & $0.052^{* * *}$ \\
& $(0.017)$ \\
$\log \mathrm{K} \log \mathrm{M}$ & $\left(0.043^{* * *}\right.$ \\
& $0.0085^{* *}$ \\
$\log \mathrm{L} \log \mathrm{M}$ & $(0.007)$ \\
& $-0.045^{* * *}$ \\
Average load & $(0.012)$ \\
& $0.049^{* * *}$ \\
Average haul & $(0.002)$ \\
& $0.002^{* * *}$ \\
1977 Dummy & $0.000)$ \\
& $(0.006)$ \\
1978 Dummy & 0.000 \\
& $(0.007)$ \\
$R^{2}$ & 0.60 \\
$\mathrm{~N}$ & 1683 \\
\hline
\end{tabular}

*** indicates the coefficient is significantly different from zero at the $1 \%$ level or less;

** indicates the coefficient is significantly different from zero at the $5 \%$ level;

* indicates that the coefficient is significantly different from zero at the $10 \%$ level. 